\title{
Vulnerability of Developing Brain. V. Effects of Fetal and Postnatal Undernutrition on Regional Brain Enzyme Activities in Three-Week-Old Rats
}

\author{
B. P. F. Adiard ${ }^{[24]}$ and John Dobbing \\ Department of Child Health, University of Manchester, Manchester, England
}

\begin{abstract}
Extract
Normal and undernourished 3-week-old rats were examined for activity of crude mitochondrial acetylcholinesterase (a marker for nerve-ending particles) in four brain areas. Littermates of these animals were used for determination of four other brain enzymes which are known to increase in activity during rat brain growth. Significant deficits (in units per gram wet weight) in crude mitochondrial acetylcholinesterase activity were found in the forebrain (normal $=2085$, malnourished $=1444$ ), brainstem (normal $=709$, malnourished $=536$ ), and olfactory lobes (normal $=74$, malnourished $=46$ ) of undernourished animals. When enzyme activities were expressed in terms of tissue wet weight, whole brain butyrylcholinesterase, fumarate hydratase, and $\beta$-galactosidase were found to be unaffected by undernutrition, whereas $5^{\prime}$-nucleotidase activity was higher in undernourished ( 730 units/g dry weight) than in control animals ( 660 units/g dry weight). The results lend support to the hypothesis that those constituents of the brain which show a large increase in concentration during brain grow th are those most likely to be affected by growth retardation in early life.
\end{abstract}

\section{Speculation}

Undernutrition during the period of rat brain growth when interneuronal connectivity is being established may result in a deficit in the number of nerve-ending particles in the brain. This could imply that an impaired formation of synaptic connections may account for some of the functional changes which result from growth restriction at this time.

\section{Introduction}

We have previously reported $[2,3$ i that the development of whole brain acetylcholinesterase, EC: 3.1.1.7, in suckling rats is somewhat retarded by underfeeding the mother during pregnancy and lactation. Acetylcholinesterase is often considered to be a marker for nerve-ending particles, and, by implication, synapses. However, inasmuch as only $50-60 \%$ of the brain enzyme is present in isolated nerve-ending particles [6,
12], whereas considerable activity resides in the microsomal fraction $[1,6,20]$, it cannot be consiclered a very specific index of these structures in whole homogenates. It may be reasonable to use the enzyme activity in the crude mitochondrial fraction as a measure of the activity in nerve endings in view of the following three considerations: $(a)$ nerve-ending particles sediment largely in the crude mitochondrial fratction [12, 20]; (b) purified mitochondria contain very little ace- 
tylcholinesterase $[1,6]$; and $(c)$ most of the enzyme activity of a crude mitochondrial fraction is recoverable in a relatively pure preparation of nerve-ending particles $[6,12]$.

We have examined normal and undernourished 3week-old rats for activity of crude mitochondrial acetylcholinesterase in four brain areas. Littermates of these animals have been used for determination of four other brain enzymes which are known to increase in activity during rat brain growth: butyrylcholincsterase, I:C 3.1.1.8 [14], fumarate hydratase, EC 1.2.1.2 [4], 5'-nucleoticlase, E.: 3.1.3.5 [6], and $\beta$-gatlactosidase, EC: 3.2. I.23 [8].

\section{Methods}

\section{Animals}

Rats were of a hooded strain. The maternal fenales had successfully reared one litter. The day of mating was assessed by a daily examination of vaginal smears for sperm. Control dams were given food [21] and water ad libitum throughout. Undernourished dams were given the same food in restricted quantity, with water ad libitum, from the 7 th daly of gestation; the (liet represented approximately $50 \%$ of the food intake of control rats and consisted of $10 \mathrm{~g}$ of food per day during pregnancy, followed by 15,20 , and $25 \mathrm{~g}$ of food claily cluring successive postnatal weeks of the suckling periol.

All litters were recluced to eight animals (four males, four females) at birth. Any litter which subsequently numbered lewer than six was discarded. A total of five control and five undernourished litters were reared to 2I clays in these experiments. All animals were then killed by an overdose of ether. In addition, a number of newborn animals were used as indicated in the footnotes to Tables $I$ and $I I$.

\section{Acetyleholinesterase}

Crude mitochondrial acetylcholinesterase was assayed in the brains of four animals (two males, two females) from each litter on the clay of killing. Brains were separated from the spinal cord at the foramen magnum, and were dissected into brain stem, cerebellum, forebrain, and olfactory lobes. Brainstem and forebrain were separated rostral to the superior colliculi. Individual brain regions were pooled from two animals of the same sex, and a crude mitochondrial fraction was prepared [11]. Acetylcholinesterase was assayed at $\mathrm{pH} 7.4$ [3], using acetylthiocholine [22] as substrate [15] and an incubation temperature of $25^{\circ}$.

\section{Other Enzy'mes}

Whole brains from the remaining animals ( 18 conwols, 15 undernourished) were stored at $-20^{\circ}$ for 1 month. It was established in preliminary experiments that this storage does not affect the activities of the enzymes examined. On thawing, the tissue was homogcnized in $0.32 \mathrm{~m}$ sucrose. Fumarale hydratase was immediately assayed [19] in 'Tris-HCi buffer $(\mathrm{pH} 7.4$, final concentration $0.05 \mathrm{M}$ ) at $25^{\circ}$. Other enzymes were assayed after storage of the homogenates for 1-4 days. Butyrylcholinesterase activity was determined at $25^{\circ}$, using butyrylthiocholine $[22]$ as substrate $[15]$ in Tris-HCl bulfer ( $\mathrm{pH} 7.4$, final concentration $0.05 \mathrm{M}$ ). 5'-Nucleotidase was determined by measuring the inorganic phosphate released [16] after incubation $\left(37^{\circ}\right)$ of adenosine $5^{\prime}$-monophosphate $(5.0 \mathrm{~mm})$ with tissue in Tris-HCl buffer ( $\mathrm{pH} 7.4$, final concentration $0.05 \mathrm{M}$ ). $\beta$-Galactosidase was determined with $p$-nitrophenyl- $\beta$ D-galactoside as substrate, using the method previously described for $\beta-N^{\top}$-acetylglucosaminidase [3]. The enzyme activities examined exhibited linear kinetics with respect to tissue concentration and time of incubation.

Protein was determined by the method of Lowry el al. [18]. The nomprotein solids were calculated by difference.

\section{Results}

\section{Brain Weights and Gross Composition}

Matemal undernutrition during pregnancy and lac. lation resulted in 3-week-old young having a brain weight deficit of 20-22\% compared with control rats. The corresponding body weight deficit was $64 \%$.

The cercbellum was the region of the brain most affected (Table I). When the deficits in each individual undernourished animal were expressed in terms of the mean control value, the percentage reduction in cerebellar weight was significantly $(P<0.02)$ greater than that of either the forebrain or the brainstem.

The concentration of solicls was significantly less in the brains of undernourished than of control animals (Table II). When solids were divided into protein and nonprotein components, the concentration of the latter, but not the former, was significantly reduced in undernourished animals (Table II).

\section{Acetylcholinesterase in the Crude Mitochondrial Frac- tion}

Significant deficits in crude mitochondrial acetylcholinesterase activity (expressed per gram wet weight of tissue) were found in the forebrain, brainstem, and 
Table I. Acetylcholinesterase (AC:E) activity in the crude mitochondrial fractions ${ }^{1}$

\begin{tabular}{|c|c|c|c|c|c|}
\hline & Control at birth: & Control at age 21 days $^{3}$ & Undernourish & hed at age 21 days 3 & $\begin{array}{l}\text { Percentage deficits } \\
\text { in } A C E \text { activity } \\
\text { in undernourished }\end{array}$ \\
\hline Body wt, g & 5.7 & $45.7 \pm 5.4$ & 16.5 & \pm 2.9 & $-64 \% 5$ \\
\hline \multicolumn{6}{|l|}{ Forcbrain } \\
\hline Wt, g & 0.1378 & $0.9501 \pm 0.02: 37$ & 0.7783 & \pm 0.0701 & $-18 \% \%^{5}$ \\
\hline $\mathrm{ACE}$, units/g wet wt & 196 & $2193 \pm 118$ & 1843 & \pm 253 & $-16 \% \%^{5}$ \\
\hline Wt, $g$ & 0.0123 & $0.1905 \pm 0.0074$ & 0.1357 & \pm 0.0212 & $-290 / c^{5}$ \\
\hline. $\mathrm{CE}$, units/g wet wt & 258 & $716 \pm 156$ & 634 & \pm 121 & $-11 \% c^{6}$ \\
\hline ICE, units/region? & 3.0 & $136.5 \pm 29.3$ & 84.5 & \pm 13.6 & $-38 \% \%^{5}$ \\
\hline \multicolumn{6}{|l|}{ Brainstem } \\
\hline Wt, g & 0.0808 & $0.2394 \pm 0.0047$ & 0.1960 & \pm 0.0131 & $-18 \% c^{5}$ \\
\hline ACE, units/g wet wt & 426 & $296.5 \pm 179$ & 2742 & \pm 123 & $-8 c, \pi$ \\
\hline$\Lambda C E$, units/regions & 1.0 & $74.7 \pm 11.4$ & 46.0 & \pm 12.5 & $-38 \% \%^{5}$ \\
\hline
\end{tabular}

1 One unit of cnzyme activity $=1 \mathrm{~m} \mu$ mole substrate consumed $/ \mathrm{min}$.

${ }^{2}$ Based on 12 animals from 2 litters. Brain regions from animals of each litter (threc males, three fcmales) were pooled for assay. Results are expressed as the mean of two litters.

${ }^{3}$ Based on 10 litters, 5 control and 5 undernourished, with 4 animals (2 male, 2 female) from each. Brain regions from animals of the same sex of each litter were pooled. Since equal mumbers of males and females were used, results were pooled for statistical analysis and are expressed as mean \pm sn.

${ }^{4}$ Significance tests compare data in control and undernourished at 21 days of age.

${ }^{5} P<0.001$.

${ }^{6}$ Not significant. $\quad{ }^{7}<0.01$.

olfactory lobes of undernourished animals when compared with control animals (Table $\mathbf{l}$ ). Dry weight (leterminations on forebrain permitted expressing the enzyme activity in terms of tissue dry weight. Expressed in this waly, activity remained significantly less $(P<0.001)$ in the undernourished animals.

Undernutrition resulted in significant deficits in crucle mitochondrial acetylcholinesterase activity per whole region in the four regions examined (Table $\mathrm{I}$ ). Deficits were greatest in the cerebellum and olfactory lobes.

\section{Other Enzymes in Whole Brain}

Other enzyme activities were expressed in terms of wet weight, tissue protein, and (lry weight (Table II). Differences between undernourished and control 3week-old animals were found only for fumarate hydratase and 5'-nucleotidase activity. For the former, enzyme activity per gram (Iry weight was higher in the undernourished group. 5'-Nucleotidase activity expressed in terms of any of the three parameters was slightly but significantly raised in the brains of undernourished animals. The results on $5^{\prime}$-nucleotidase dif- fer somewhat from those of Banik and Davison [6] who found lower enzyme activity at 21 days of age but a 3.5-fold increase from 12 to 21 clays of age. This is compared with a much smaller increase between birth and 21 days (Table II) and suggests that the enzyme activity may pass through a trough. It should be noted, however, that the assay systems differed in that potassium and magnesium ions were omitted in the present study.

\section{Discussion}

It is well known [17] that there are large regional variations in acetylcholinesterase activity throughout the brain. 'This may represent the varying importance of cholinergic neurons relative to other types. It is apparently possible to clistinguish cholinergic nerve endings from noncholinergic norve endings [12] as the latter contain negligible amounts of acetylcholine or acetylcholinesterase. We suggest that acetylcholinesterase in a crude mitochondrial fraction may be used as an approximate marker for nerve endings, or, more probably, cholinergic nerve endings. 
Table 11 . Ictivity of four enzymes ${ }^{1}$ in whole brains of control and undernourished 3 -weck-old aninals and of control animals at birth

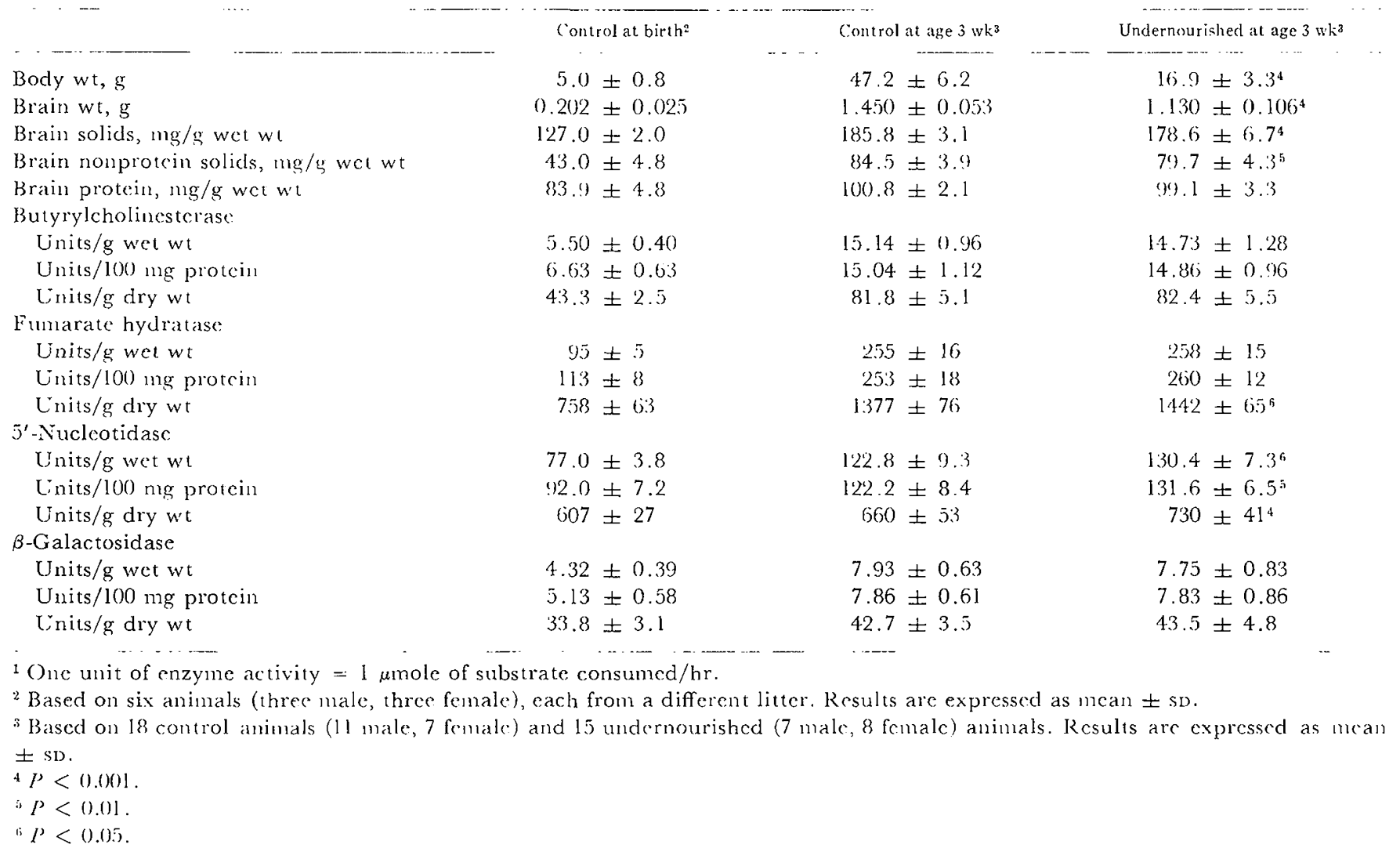

We have found that undemutrition results in deficits in the crucle mitochondrial acetylcholinesterase aclivity of brainstem, forebrain, and olfactory lobes. If the ensme activity in the crude fraction predominanty represents symatosomal acelylcholinesterase, this might suggest a decreased concentration of nerve condings, or, alternatively, a nomal complement of nerve enclings with each having less enryme aclivity.

Ihis result should be considered in relation to a recent histologic study [7] of the effects of neonatal unclemutrition on the rat somatosensory cortex in which reducel fomation of symapses was reported. It has also been shown that neonatal hypothyroidism, some of whose cflects on the leveloping brain are similar to those of undermutrition, causes a deficit in the activity of glutamate decarboxylase, an enzyme located in nerve endings [5], whereas lactate dehydrogenase (cytoplasmic) and glutamate delsydrogenase (mito(hombrial) are mallected.

It is al first sumprising hat undernutrition had no effect on the cerebellar acetylcholinesterase activity since, in terms of weight, the cerelocllum was more alfected than any other region. On the other hand, the absolute entyme activity was relatively low in the cerebellum (at 3 weeks), and showed a relatively small increase (approximately 3 -fold) during the first 3 weeks of life. This might support the hypothesis that the vulnerability of the levels of a brain constituent to alteration by molernutrition may be related to the degree of increase of that constituent during the brain growth spurt [13]. For example, the increase in acetylcholinesterase activity in the first 21 days (6-10-fold) is large in three of the lour regions, excluding the cerebellum, and only in these regions is there substantial recluction catused by undernutrition. By contrast, butyrylcholinesterase, fumarate hydratase, and $\beta$-gatlactosidase show only moderate developmental increase (2-3-fold) and these are all unaffected by undernutrition. $5^{\prime}$-Nucleotidase, which normally has a comparatively small increase at this time, even shows excess activity in the unclernourished brain.

The finding that mulernutrition during development results in a reduced concentration of nonprotein solicls (presumably largely lipid), whereas the protein concentration is unaffected, is consistent with the findings of Culley and Mertz [10]. I'hose workers found 
that in brain the concentration of total lipid, but not the concentration of nonlipid solids, was adrersely alfected by undernutrition. 'These results may also be considered in terms of the possible vulnerability of substances whose concentrations increase most markedly during brain growth. Whereas nonprotein solicls increased in concentration by $97 \%$ between birth and 3 weeks, the protein concentration increased by only $20 \%$ during this same period.

In general, the results confirm $[3,9]$ that undernutrition in early life may alter the enzymic composition of the brain of the young rat. The changes are, however, relatively small, and it is at present impossible to state whether they may have functional significance.

\section{Summary}

Fetal and postnatal undernutrition resulted in changes in enzyme activities, but not in total protein concentration, in the brains of 3-week-old rats. Crude mitochondrial acetylcholinesterase activity was less in three regions of the brain of unclernourished animals than in control animals, whereas the undernourished group hatl higher whole brain 5'-nucleoticlase activity. Fumarate hyclratase activity also increased in the undernourished animals when expressed in terms of tissue dry weight, although it was unchanged in terms of wet weight. The results lend support to the hypothesis that those constituents of the brain which show a large increase in concentration during brain growth are those most likely to be affected by growth retardation in early life.

\section{References and $N^{\text {rotes }}$}

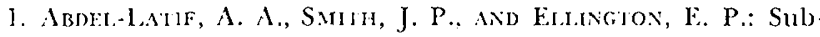
cellular distribution of sodium-potassium adenosine triphos. phatase, acetylcholine and acetylcholinestcrase in developing rat brain. Brain Res., 18: 441 (1970).

2. Avtakd, B. P. F., DobBis, J., ANd Sirart, J. L.: Endemutrition and the decelopment of certain enzymes in rat brain. Biochem. J., 119: 46P (1970).

3. Adt.ARD, B. P. F., AND DoBbing, J.: Vulnerability of (Jeveloping brain: III. Development of four enzymes in the brains of normal and undemourished rats. Brain Res., 28: 9' (1971).

4. Adrand, B. P. I., AND DoBBris, J.: Phosphofructokinase and fumalate hydratase in developing rat brain. J. Neurochem., 18: $1299(1971)$.

5. Bainzs, R., Kovacs, S., Teichgraber, P., Cocks, W. A., and EAYRs, J. 'T.: Biochemical effects of thyroid deficiency on the developing brain. J. Neurochem., 15: 1335 (1968).

6. BANIK, N. L., AND DAVISON. A. N.: Enzyme atctivity and com- position of myclin and sulfellular fractions in the develop. ing rat brain. Biochem. J., /15: 1051 (1969).

7. Bass, N. H., Netsky, M. G., AND Yot:Ni, E.: Effect of neomatal malnutxition on developing cerebrum. I. Arch. Neurol. 23: $289(1970)$.

8. BowfN, D. M., AND Radr, N. S.: Cerebroside galactosirlase: A method for determination and a comparison with other lysosomal enzymes in developing rat brain. J. Neurochem., 16: $501(1969)$.

9. Chasf, H. P., DORsfy, J., ANo MaKhani, G. M.: The effecl of maluutrition on the synthesis of a myelin lipid. Pediatrics, 10: $551(1967)$

10. CullteY, W. J., AND Mertz, E. T.: Effect of restricted food intake on growth and composition of preweanling rat brain. Proc. Soc. Exp. Biol. Med., 118: 223 (1965).

11. Cuzner, M. L., AND Davison, A. N.: The lipid composition of rat brain myelin and subcellular fractions during development. Biochem. J., 106:29 (1968).

12. De Robertis, E., De Iraidi, A. P., Arnaiz, G. R. I., ANil SAl,iAilicofF, L.: Cholinergic and non-cholinergic nerve endings in the rat brain. I. Isolation and subcel ular distribution of acetylcholine and acetylcholinesterasc. J. Neurochem., 9: $23(1962)$.

13. Doвbrns, J.: Vulncrable periods in developing brain. In: A. $\therefore$. Darison and J. Dobbing: Applied Neurochemistry, p. 287. (Blackwcll, Oxford, 1968).

11. Fikrs, J., AND 'Tonrick, A.: On the development of cholinesterases in the rat brain. In: M. Waclsch: Biochemistry of the Developing Nervous System, p. 309. (Academic Press, New York, 1955).


STONE, R. M.: A new and rapid colourimetric determination of acetylcholinesterase activity. Biochem. Pharmacol., $7: 88$ (1961).

16. IISkE, (.. H., ANb SubBarow, Y.: The colorimetric determination of phosphorus. J. Biol. Chem., 66: 375 (1925).

17. Freme, R. L.: 'Topographical Brain Chemistry, p. 246. (Academic Press, New York, 1966).

18. LoWri. O. H., Rosebrogigh, N. J., Farr, A. I... AND Ranidl., R. J.: Protein measurement with the folin phenol reagent. J. Biol. Chem., 193: 265) (1951).

19. RACKER, E.: Spectrophotonctric measurements of the chry matic formation of fumaric and cis-aconitic aciels. Biochim. Biophys. Acla, f: 211 (1950).

20. Whimtaker, V. P.: The application of subcellular fractionation techniques to the study of brain function. Progr. Biophys. Mol. Biol., 15: 41 (1965).

21. Breceling dict for rats and mice supplied by Oxoid Itel., I.ondon, England.

22. Sigma Chemical Co., St. Louis, Mo.

23. Supported by a grant from the Medical Research Council. The authors are also grateful to the National fund for $\mathrm{Re}$. search into Crippling Diseases and to the Spastics Socicty for their help.

24. Recuests for reprints should be addressed to: B. P. F. ADLARD. Ph.D., Department of Child Health, Cniversity of Manchester. Clinical Sciences Building, York Place, Manchester 13, England.

25. Accepted for publication April 16, 1971 . 